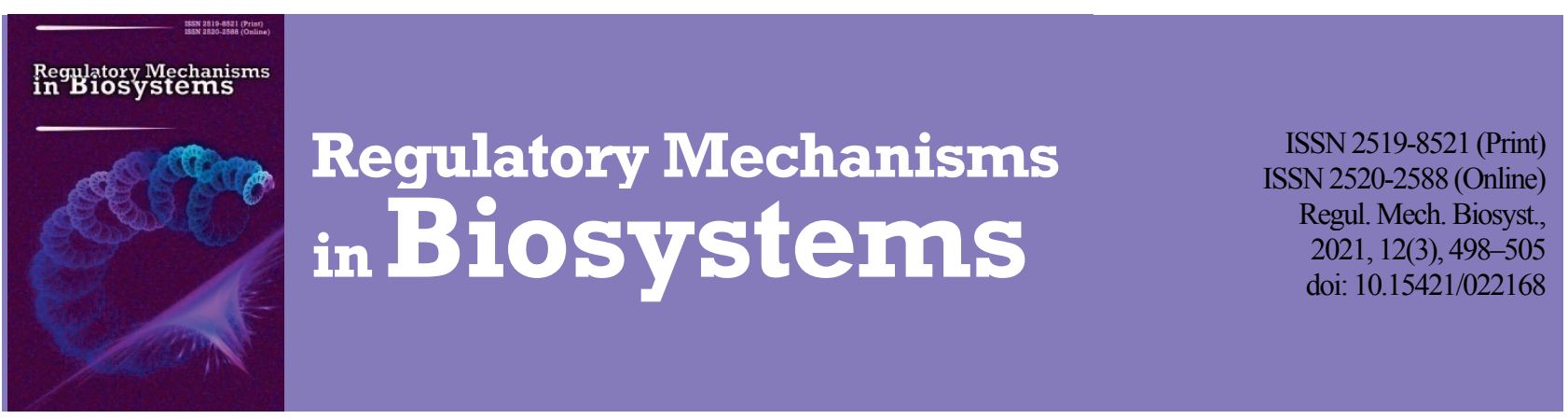

\title{
Beneficial traits of grain-residing endophytic communities in wheat with different sensitivity to Pseudomonas syringae
}

\author{
A. Pastoshchuk*, Y. Yumyna*, P. Zelena*, V. Nudha**, V. Yanovska**, \\ M. Kovalenko*, N. Taran*, V. Patyka***, L. Skivka* \\ *Taras Shevchenko National University of Kyiv, Kyiv, Ukraine \\ **Institute of Microbiology Diagnostics, Kyiv, Ukraine \\ ***D. K. Zabolotny Institute of Microbiology and Virology of National Academy of Sciences of Ukraine, Kyiv, Ukraine
}

Article info

Received 26.07.2021

Received in revised form 22.08.2021

Accepted 23.08.2021

Taras Shevchenko National University of Kyiv,

Volodymyrska st., 64

Kyiv, 01033, Ukraine

Tel. +38-097-899-50-11.

E-mail:kotsyuk93@ukr.net

Institute of Microbiology

Diagnostics, Peremohy av.

119-121, Kyiv, 03115, Ukraine.

Tel. +38-067-402-68-03.

E-mail:

yanovskaya-valya@ukr:net

D. K. Zabolotny Institute

of Microbiology and Virology

of National Academy of Sciences

of Ukraine, Akademika

Zabolotnoho st., 154,

Kyiv, 03680, Ukraine.

Tel.: +38-050-510-74-91.

E-mail:

patykavolodymyr@gmail.com

Pastoshchuk, A., Yumyna, Y., Zelena, P., Nudha, V., Yanovska, V., Kovalenko, M., Taran, N., Patyka, V., \& Skivka, L. (2021). Beneficial traits of grain-residing endophytic communities in wheat with different sensitivity to Pseudomonas syringae. Regulatory Mechanisms in Biosystems, 12(3), 498-505. doi:10.15421/022168

Deep insight into compositional and functional features of endophytic bacterial communities residing in wheat grains opens the way to the use of their plant growth promoting and biocontrol abilities in agricultural biotechnology. The aim of this work was to compare grain-residing endophytes from winter wheat varieties with different sensitivity to Pseudomonas syringae pv. atrofaciens (McCulloch) and to examine their plant-beneficial traits and antagonistic effects. Grain-residing bacteria were isolated from surface-sterilized grains of three wheat varieties sown in Ukraine following a culture-dependent protocol, and were screened for their plant growth promotion (PGP) and antagonistic properties. Bacterial morphotypes were represented by gram-negative rods, endospore-forming bacilli and gram-positive cocci. Different resistance to phytopathogenic pseudomonads was associated with distinctive quantitative and functional features of grain-residing endophytic communities. High resistance to $P$. syringae was coupled with the prevalence of gramnegative rods in the endophytic community, the highest proportion of endophytic bacteria possessing three PGP activities (phosphate solubilization, nitrogen fixation and production of indolic compounds) simultaneously, and with the most potent antagonistic activity of grain-residing endospore-forming bacilli. In total, five grain-residing isolates, which were obtained from three wheat varieties (two isolates from varieties with medium and high resistance and one - from a low-resistant variety), demonstrated ability to restrain $P$. syringae pv. atrofaciens (McCulloch) growth. Two isolates (P6 and P10) which were obtained from the high-resistant wheat variety Podolyanka and were assigned to Paenibacillus and Brevibacillus genera according to their biochemical profiling and MS-DS identification, showed the most potent antagonistic effects as indicated by maximum inhibition zone in agar well diffusion assay. These results shed light on the association of the features of grain-residing endophytic bacteria with wheat resistance to phytopathogenic pseudomonads. Isolates from the high-resistant wheat variety can be recommended for grain dressing as plant growth promoting and biocontrol agents for P. syringae pv. atrofaciens (McCulloch).

Keywords: basal glume rot of wheat; leaf blight; agrobiotechnology; Bacillus; Paenibacillus; Brevibacillus; wheat grain-residing endophyte.

\section{Introduction}

Endophytes are microorganisms (including bacteria, fungi etc.) that live asymptomatically inside different plant tissues. Endophytic bacteria exert beneficial effects on their host plant by various direct and indirect mechanisms. The direct mechanisms include manufacturing of phytohormones, the solubilization of phosphate, nitrogen fixation, and uptake of iron to plant tissues (Papik et al., 2020). In addition, endophytic microorganisms can exert direct antagonistic effects to phytopathogens. The endophytes can compete with the phytopathogen for nutrients, produce inhibitory chemicals etc. (Karthikeyan et al., 2021). The indirect mechanism consists of the ability of endophytes to activate plant defence responses against phytopathogens. Thus, endophytic symbionts represent superior models for insight into plant-microbe interactions (Afzal et al., 2019; Morales-Cedeño et al., 2020). Moreover, beneficial properties of endophytic microorganisms exhibit great promises for their use in agrobiotechnology for sustainable agriculture (Maheshwari, 2017; Bezpal'ko et al., 2020). At the present time, the great majority of bacterial endophytes are noncultivable. Study of bacterial endophytic community using culture-independent approaches is primarily intended to extend current knowledge concerning diversity of plant tissue bacterial inhabitants (Eevers et al.,
2015). Biotechnological use of endophytes involves in turn the study and isolation of cultivable microorganisms. Biotechnologies based on cultivable endophytes are gaining significance for improving soil properties and enhancing crop yield, especially in principal cereals, such as wheat, rice etc. (Rana et al., 2015). Endophytic bacteria inhabit the intercellular area of different cereal tissues (Eid et al., 2021). Currently, most scientific reports have been concentrated on the isolation and biotechnological use of rhizosphere and root endophytic bacteria while data concerning endophytes inhabiting wheat grains are scarce (Makar et al., 2021). Nevertheless, it is grain endophytes that are of particular interest in terms of their use in agrobiotechnology due to their unique properties including the capacity to be transmitted vertically between generations (Compant et al., 2020; Kuźniar et al., 2020). Wheat grains seem to be one of the most important plant organs which harbour endophytic bacteria. Grainstored bacteria are characterized by the unique ability to reside in dormant grain and adapt to unfavourable conditions, as well representing a starting point for the establishment of endophyte communities in seedlings, influence significantly whole plant endophyte formation, and eventually, seed germination, plant growth and productivity (Herrera et al., 2016; Geisen et al., 2017; Ridout et al., 2019; Kuźniar et al., 2020). 
In our previous study we revealed different sensitivity of winter wheat varieties sown in Ukraine to P. syringae pv. atrofaciens (McCulloch, 1920) and its lipopolysaccharide (LPS) in vitro (Pastoshchuk et al., 2018). $P$. syringae is gram-negative phytopathogenic bacterium and causal agent of a variety of bacterial spot, speck, and blight diseases on a wide range of plants, including such important cereals as rice and wheat (Lamichhane et al., 2015). The contribution of $P$. syringae to crop loss is not well understood and therefore remains largely underestimated. It has been shown that grain infestation, as well as affected weeds in wheat agrophytocenoses are very important in the epidemiology of the disease (Pasichnyk, 2016; Umesha, 2020). Isolates of $P$. syringae are taxonomically divided into pathovars, based substantially on their host. There are about 50 pathovars described for P. syringae. The Pseudomonas strains causing the wheat disease "basal glume blotch" area or "basal glume rot" are classified as $P$. syringae pv. atrofaciens (McCulloch) (Valencia-Botín, 2012). In many countries, the occurrence of $P$. syringae pv. atrofaciens has only been reported once (Argentina, Australia, New Zealand, Italy, Pakistan, Iran) or has not been published (Belgium, Ethiopia and Denmark). Therefore, yield losses have never been thoroughly estimated, and no control measures for routine application have as yet been established (Kazempour et al., 2010). In an attempt to decrease the prevalent use of chemicals for preventing and treatment of phytopathogen damage to plants, the use of plant symbiotic microorganisms, including endophytic bacteria, as biocontrol agents seems to be a promising approach for eco-friendly and sustainable agriculture (Muthukumar et al., 2017).

The objectives of this pilot study were to 1) isolate and compare grain-residing endophytic communities from winter wheat varieties with different sensitivity to $P$. syringae pv. atrofaciens (McCulloch) and its LPS; 2) examine plant-beneficial traits and antagonistic effects of grainresiding endophytic bacteria towards $P$. syringae pv. atrofaciens (McCulloch) in vitro; 3 ) evaluate and compare antioxidant enzyme responses in seedling of winter wheat varieties with different sensitivity to $P$. syringae pv. atrofaciens (McCulloch) after the grain exposure to phytopathogen.

\section{Materials and methods}

Grains of three winter wheat (Triticum aestivum $\mathrm{L}$.) varieties with different sensitivity to Pseudomonas syringae pv. atrofaciens (McCulloch, 1920) Young, Dye \& Wilkie 1978: UKM B-1013 (Table 1) were first washed under running tap water for $15 \mathrm{~min}$, then were surface disinfected using ethanol $72 \%(30 \mathrm{~s})$, followed by $2 \%$ trichloroisocyanuric acid (4.5 min) and again, ethanol $72 \%(30 \mathrm{~s})$, with six rinses for $15 \mathrm{~min}$ in sterilized distilled water using shaker $(220 \mathrm{rpm})$. To test the effectiveness of grain surface sterilization, control was provided by plating $1 \mathrm{~mL}$ of sterile water used for the final rinse onto R2A agar (Scharlau, Spain). No microbial growth was detected on the medium after 7 days of incubation at $28^{\circ} \mathrm{C}$. This result indicated successful surface sterilization for killing or inhibiting the growth of the epiphytic bacteria. Thus, microbial isolates were considered to be true endophytes. For the counting bacterial endophyte CFU, surface sterilized (as described above) wheat grains (1 g) were transferred to a sterile mortar with $9 \mathrm{~mL}$ of $10 \mathrm{mM}$ phosphate buffer (pH 6.5) and homogenized using a sterile pestle. A volume of $1 \mathrm{~mL}$ was transferred to $9 \mathrm{~mL}$ of $10 \mathrm{mM}$ phosphate buffer. A serial dilution was made, and each dilution was plated in triplicates on: potato agar for total bacteria count; McConkie agar for Gram-negative bacteria count (HiMedia, India), MYP agar (HiMedia, India) for bacilli count. Plates were incubated at $24^{\circ} \mathrm{C}$, and examined regularly for visible bacterial growth.

\section{Table 1}

Characteristics of winter wheat cultivars used in the study

\begin{tabular}{|c|c|c|c|c|}
\hline $\begin{array}{c}\text { Cultivar } \\
\text { name }\end{array}$ & $\begin{array}{l}\text { Winter } \\
\text { hardiness }\end{array}$ & $\begin{array}{l}\text { Drought } \\
\text { tolerance }\end{array}$ & $\begin{array}{l}\text { Fungal } \\
\text { diseases } \\
\text { resistance }\end{array}$ & $\begin{array}{l}\text { Resistance to P.syringaepv. } \\
\text { atrofaciens (McCulloch) } \\
\text { (Pastoshchuk et al., 2018) }\end{array}$ \\
\hline $\begin{array}{l}\text { Podo- } \\
\text { lianka }\end{array}$ & high & high & medium & $\begin{array}{l}\text { high (seed germination is non-affected; } \\
\text { root growth is inhibited by } 20 \% \text { ) }\end{array}$ \\
\hline Discus & high & high & high & $\begin{array}{l}\text { medium (seed germination is slightly } \\
\text { retarded; root growth is inhibited by } 38 \% \text { ) }\end{array}$ \\
\hline $\begin{array}{l}\text { Favo- } \\
\text { rytka }\end{array}$ & high & medium & high & $\begin{array}{l}\text { low (seed germination is inhibited by } \\
28 \% \text {; root growth - by } 4 \text { times) }\end{array}$ \\
\hline
\end{tabular}

For isolate characterization and identification, ten surface-sterilized grains were placed on Petri dishes containing R2A culture medium (five replicates). All Petri dishes were then incubated at $28{ }^{\circ} \mathrm{C}$ for $72 \mathrm{~h}$. The term of incubation was limited by an extensive endophytic fungi growth from grains of some varieties after $72 \mathrm{~h}$. Representative colonies emerging on the majority of Petri dishes were then selected and grouped according to their morphological characteristics, including margin, shape, colour, viscosity, elevation and opacity in order to select different colonies.

Several isolates were obtained from each wheat cultivar after repeated subcultures. These isolates were then characterized using standard protocols based on morphology, Gram staining, spore formation. Additionally, bacterial isolates were screened for potential plant growth promoting activities, as well as for antagonistic activity towards $P$. syringae pv. atrofaciens in vitro. A strain of $P$. syringae pv. atrofaciens (McCulloch) Young, Dye \& Wilkie, 1978: UKM B-1013 was used for the in vitro assay of endophytic bacteria antagonistic activity. Phytopathogenic bacteria were grown on potato agar at $28^{\circ} \mathrm{C}$ for $24-48 \mathrm{~h}$. Biochemical profiling and MALDI-TOF mass spectrometry were used for the identification of microorganisms.

The screening of endophytic bacteria for indolic compounds' production was performed by cultivating in liquid medium supplemented with L-tryptophan $(250 \mu \mathrm{g} / \mathrm{mL})$ (HiMedia, India) at $28{ }^{\circ} \mathrm{C}$ in the dark under constant agitation of $140 \mathrm{rpm}$ for $48 \mathrm{~h}$. The presence of indolic compounds was estimated by adding Salkowski's reagent (Sadaf et al., 2009).

The ability of the isolates to solubilize inorganic phosphate was evaluated by observing halo formation around bacterial colonies after incubation for 7 days at $28{ }^{\circ} \mathrm{C}$ in Muromtsev agar $\left(0.2 \mathrm{~g} / \mathrm{L} \mathrm{K}_{2} \mathrm{SO}_{4}, 0.2 \mathrm{~g} / \mathrm{L}\right.$ $\mathrm{MgSO}_{4} \times 7 \mathrm{H}_{2} \mathrm{O}, 10 \mathrm{~g} / \mathrm{L}$ glucose, $1.0 \mathrm{~g} / \mathrm{L}$ asparagine, $3.3 \mathrm{~g} / \mathrm{L} \mathrm{CaCl}_{2}, 3.8 \mathrm{~g} / \mathrm{L}$ $\mathrm{Na}_{3} \mathrm{PO}_{4}$, and $15 \mathrm{~g} / \mathrm{L}$ agar) supplemented with $3,0 \mathrm{~g} / \mathrm{L}$ of $\mathrm{Ca}_{3}\left(\mathrm{PO}_{4}\right)_{2}$ (pH 6,8) (Alikhani et al., 2006). Screening of oligonitrotrophic isolates was performed using the inoculation of fresh colony onto nitrogen-free Ashby's mannitol agar (Woźniak et al., 2019).

The ability of endophytic bacterial isolates to inhibit the phytopathogenic strain of $P$. syringae pv. atrofaciens was determined using agar well diffusion assay as described by Agarwal et al. (2020), with slight modifications. The overnight culture of phytopathogenic bacteria (OD600 0.4) and endophytic isolates (OD600 0.4) in PBS were prepared. Sterilized Petri dishes containing R2A agar (Scharlau, Spain) were spread inoculated with $100 \mu \mathrm{L}$ of $P$. syringae pv. atrofaciens culture. A well ( $1 \mathrm{~cm}$ diameter) was made in the centre, and $60 \mu \mathrm{L}$ of each endophytic isolate was added and incubated at $28 \pm 2{ }^{\circ} \mathrm{C}$ for $24 \mathrm{~h}$. A plate inoculated with sterile water was used as control. Antagonistic activity was evaluated based on the production of inhibition zone around the well.

Biochemical profiling of isolates was performed using Vitek $^{\mathbb{R}}$ 2Compact (bioMérieux SA, France) according to the system manufacturer recommendations. Briefly, a pure 18-24 h bacterial culture was accumulated on appropriate nutrient media (bioMerieux, France). A bacterial suspension was adjusted to a McFarland standard of 1.8-2.2 in a Vitek Saline Solution (bioMérieux SA, France) using DensiChek Plus (bioMerieux SA, France). Analysis was done using the identification BCL cards. Data were analyzed using the Vitek 2C software version 08.01 according to the manufacturer's instructions (www.biomerieux.pl).

For the identification by Maldi-Tof mass spectrometry, a pure 18$24 \mathrm{~h}$ bacterial culture was accumulated on appropriate nutrient media. A portion of not more than half of the microbiological loop with a diameter of $1 \mathrm{~mm}$ was smeared onto the spots of Vitek MS-DS disposable target slides and then the spot was covered with $1 \mu \mathrm{L}$ of Vitek MS-CHCA solution (bioMérieux SA, France). Spots were completely air dried. After this, the slides were placed on an adapter and inserted to Vitek MS instrument. Spectra were generated using the Myla software version 3.0.0, Myla version 4.6.1 (bioM'erieux, France) and the identification was automatically done with the Vitek MS. The software compares the spectrum obtained to the expected spectrum of each organism. After this, the percent probability, a quantitative value, is calculated for each sample. The range of percent probabilities for a correct identification is from 60 to 99 with values closer to 99.9 indicating a closer match. When the obtained percent probability is under 60 , then it was considered as no identification. Confidence level is determined with percent probability and number of choices (Rychert et al., 2013). 
For the determination of anti-oxidant systems of wheat grains in response to phytopathogen exposure, 20 surface sterilized wheat grains were placed on moisturized filter paper in Petri dishes. $5 \mathrm{~mL}$ of distilled water (control) or $5 \mathrm{~mL}$ of phytopathogenic bacteria suspension at the concentration of $10^{9} \mathrm{CFU} / \mathrm{mL}$ (treated) were then applied to the Petri dishes. Grains were germinated for 7 days in humidified atmosphere at $27^{\circ} \mathrm{C}$. Sevenday-old seedlings were then used for the determination of thiobarbituric acid reactive substances (TBARS), the antioxidant enzyme assays, and proline content. All these experiments were repeated at least three times. Total TBARS (expressed as malondialdehyde (MDA) equivalents) was examined as described by Kumar \& Knowles (1993). Total Superoxide Dismutase (SOD, EC 1.15.1.1) activity was examined using a modified NBT method (Beyer et al., 1987). Catalase (CAT, EC 1.11.1.6) activity was examined according to Aebi (1984). The content of proline was examined spectrophotometrically as described by Bates et al. (1973).

All experimental results are presented as means \pm standard deviation $(\mathrm{x} \pm \mathrm{SD})$ of at least three independent experiments. Statistical differences were calculated using ANOVA with Tukey's post-hoc test for multiple comparisons, and a two tailed T-test for single comparisons. Differences were considered significant at $\mathrm{P}<0.05$.

\section{Results}

A total of thirty two endophytic bacteria isolates were obtained from dry grains of three commercial winter wheat varieties with different susceptibility to $P$. syringae pv. atrofaciens (Fig. 1). Ten bacterial isolates were obtained from grains of Favorytka - wheat variety with medium-tohigh stress-tolerance and low resistance to $P$. syringae pv. atrofaciens (Table 1). Eleven isolates - from wheat variety with high stress-tolerance and medium resistance to the phytopathogen (Discus). The same number of grain-residing endophytic bacteria (eleven isolates) were obtained from Podolianka - wheat variety with medium-to-high stress-tolerance and high resistance to P. syringae pv. atrofaciens (McCulloch). Bacterial morphotypes were represented by gram-negative rods, endospore-forming bacilli and gram-positive cocci. Gram-negative rods slightly predominated in grain-residing endophytes of high-resistant wheat variety. Endosporeforming bacilli were the highly predominant morphotype in grain-residing endophytes of wheat cultivar with medium resistance to the phytopathogen. In wheat cultivars with low resistance to phytopathogenic pseudomonads, the proportion of gram-positive cocci in the grain-residing endophytic community was higher than in varieties with high and medium resistance.

The abundance of endophytic bacteria in the grains of different wheat cultivars varied from $1.7 \times 10^{2}$ to $2.5 \times 10^{5} \mathrm{CFU}$ per $\mathrm{g}$ of dry weight. The highest value $\left(2.5 \pm 1.0 \times 10^{5}\right)$ was found in grains of Discus wheat cultivar with medium phytopathogen resistance, and the lowest value $\left(1.7 \pm 0.5 \times 10^{2}\right)$ was registered in grains of Favorytka wheat cultivar with low resistance to phytopathogenic pseudomonads.

Out of 32 bacterial isolates, 20 (62.5\%) exhibited different PGP activities: 10 isolates exhibited the ability to solubilize phosphates, $10-$ to grow on nitrogen-free Ashby's medium (oligonitrotrophs), and 10 - to produce indolic compounds. The highest proportion of bacteria with PGP activities was revealed in endophyte harbouring grains of highly phytopathogen-resistant wheat variety Podolianka. This grain-residing endophytic community contained members with all mentioned PGP activities. Phosphate-solubilizing gram-negative rods with the ability to produce indolic compound predominated there. PGP potential of grain-residing community from the wheat variety with medium resistance to phytopathogenic pseudomonads (Discus) was represented mainly by oliginotrotrophic endospore-forming bacilli with weak ability to produce indolic compound. Endophytes of low-resistant variety contained the lowest proportion of bacteria with PGP activities. Oligonitrotrophic indole-producing endospore-forming bacilli as well as phosphate-solubilizing gram-negative rods were present (Fig. 2). Surprisingly, gram-positive cocci from grain-residing endophytic communities in all studied winter wheat varieties exerted no PGP activities. Some of the endophyte isolates exhibited two or even three different PGP activities simultaneously (Fig. 3). It is necessary to point out that the highest proportion of grain-residing bacterial isolates exhibiting all three PGP activities was registered in the wheat variety with highest resistance to phytopathogenic pseudomonads (Fig. 3c). At the same time, oligonitrotrophs without any additional PGP activity were absent in this endophytic community. A distinctive feature of the endophyte of the wheat variety with low resistance to the phytopathogen (Fig. 3a) was increased content of bacteria producing indolic compounds.

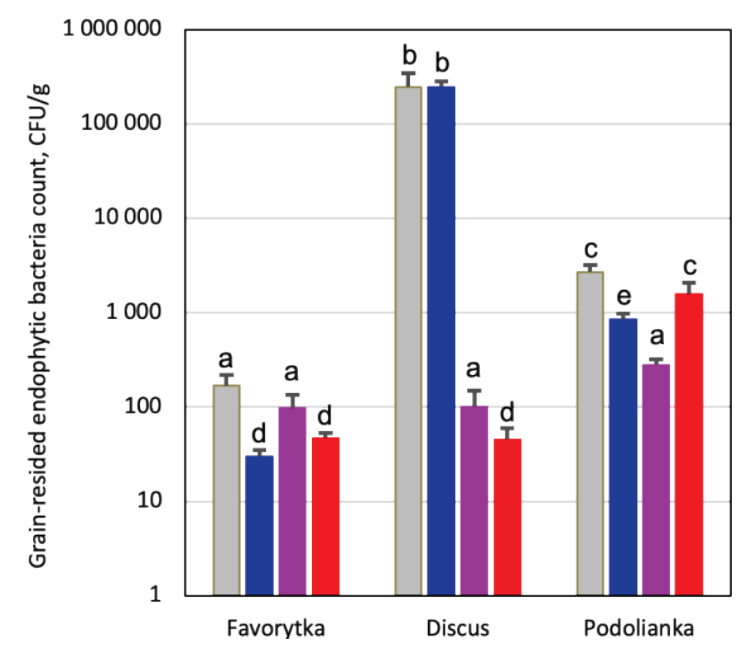

Fig. 1. Quantitative characteristics and morphotypes of grain-residing bacterial endophytic communities in wheat cultivars with different sensitivity to Pseudomonas syringae pv. atrofaciens (McCulloch):

grey columns - total bacteria count; blue columns - endospore-forming bacilli; pink columns - cocci; red columns - gram-negative rods; values in bar graphs are presented as $\mathrm{x} \pm \mathrm{SD}(\mathrm{n}=3)$; different letters indicate significant differences between varieties (Tukey post-hoc test with Bonferroni correction, $\mathrm{P}<0.05$ )

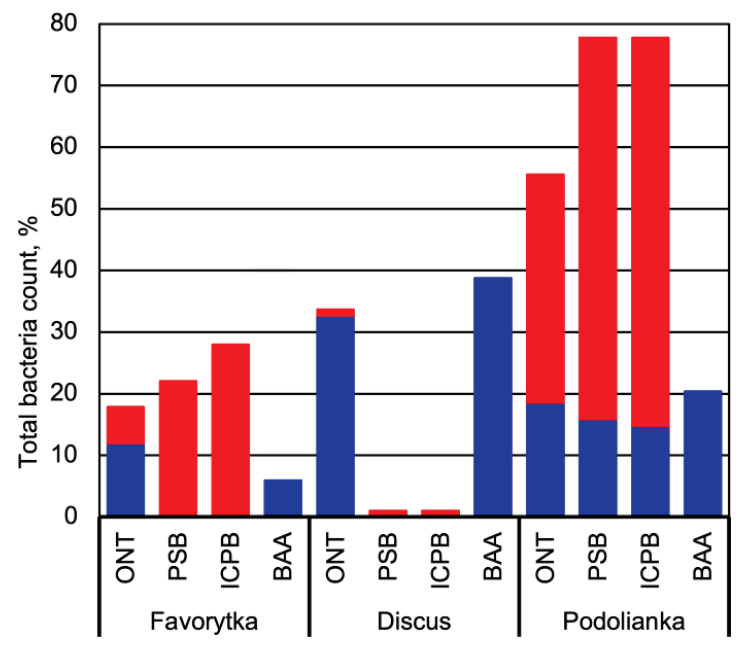

Fig. 2. Plant-beneficial characteristics of grain-residing bacterial endophytic communities in wheat cultivars with different sensitivity to Pseudomonas syringae pv. atrofaciens (McCulloch): blue-

endospore-forming bacilli; red - gram-negative rods; values in bar graphs are presented as proportions in total bacteria count $(\mathrm{x} \pm \mathrm{SD}, \mathrm{n}=5)$; ONT - oligonitrotrophs, PSB - phosphate solubilizing bacteria, ICPB - indolic compound producing bacteria, BAA - bacteria with antagonistic activity against P. syringae pv. atrofaciens (McCulloch)

Antagonistic activity of the isolated grain-residing endophytic bacteria was checked against $P$. syringae pv. atrofaciens in vitro. Endophytic bacteria with antagonistic activity against phytopathogenic pseudomonads were present in the grain-residing communities of all studied wheat varieties. The proportion of bacteria with antagonistic activity was highest in the endophytic community of Discus $(39 \%, 95000 \mathrm{CFU} / \mathrm{mL})$, followed by the endophytic community of Podolyanka $(20 \%, 550 \mathrm{CFU} / \mathrm{mL})$. The lowest proportion $(6 \%, 10 \mathrm{CFU} / \mathrm{mL})$ of endophytic antagonists inhabited grains of the low-resistant variety Favorytka. All endophytic bacteria 
with antagonistic activity belonged to the endospore-forming bacilli morphotype (Fig. 2). Out of 32 tested isolates, 5 showed varying extents of antagonistic potential against the $P$. syringae pv. atrofaciens by forming characteristic clear zones inhibiting the growth of the pathogen around the well. Bacteria with antagonistic activity were then preliminarily identified by their biochemical profile and using MALDI-TOF mass-spectrometry. Two isolates with antagonistic activity (P6 and P10) were obtained from Podolianka variety. P10 showed the most pronounced antagonistic activity (inhibition zone diameter $27.0 \pm 3.0 \mathrm{~mm}$ ), and was identified as Paenibacillus peoriae according to its cultural and morphological properties and biochemical profiling (Fig. 4a, Table 2). P6 also demonstrated potent antagonistic activity (inhibition zone diameter $23.0 \pm 1.0 \mathrm{~mm}$ ), and was identified as Brevibacillus spp. (Fig. 4b, Table 2). Two isolates (D2 and D5) were obtained from Discus variety, and were identified as Bacillus spp. and Bacillus pumilus correspondingly (Fig. 4c, d, Table 2). These isolates exerted moderate and strong antagonistic effects: inhibition zone diameters $15.0 \pm 2.0$ and $24.0 \pm 4.0 \mathrm{~mm}$ correspondingly. One isolate (F1) with antagonistic activity (inhibition zone diameter $21.0 \pm 3.0 \mathrm{~mm}$ ) from Favorytka was identified as Bacillus spp. (Fig. 4e, Table 2). It should be noted that P6 and P10 isolates were characterized by potent phosphatesolubilizing activity and moderate oligonitrotrophy in addition to their antagonistic action.
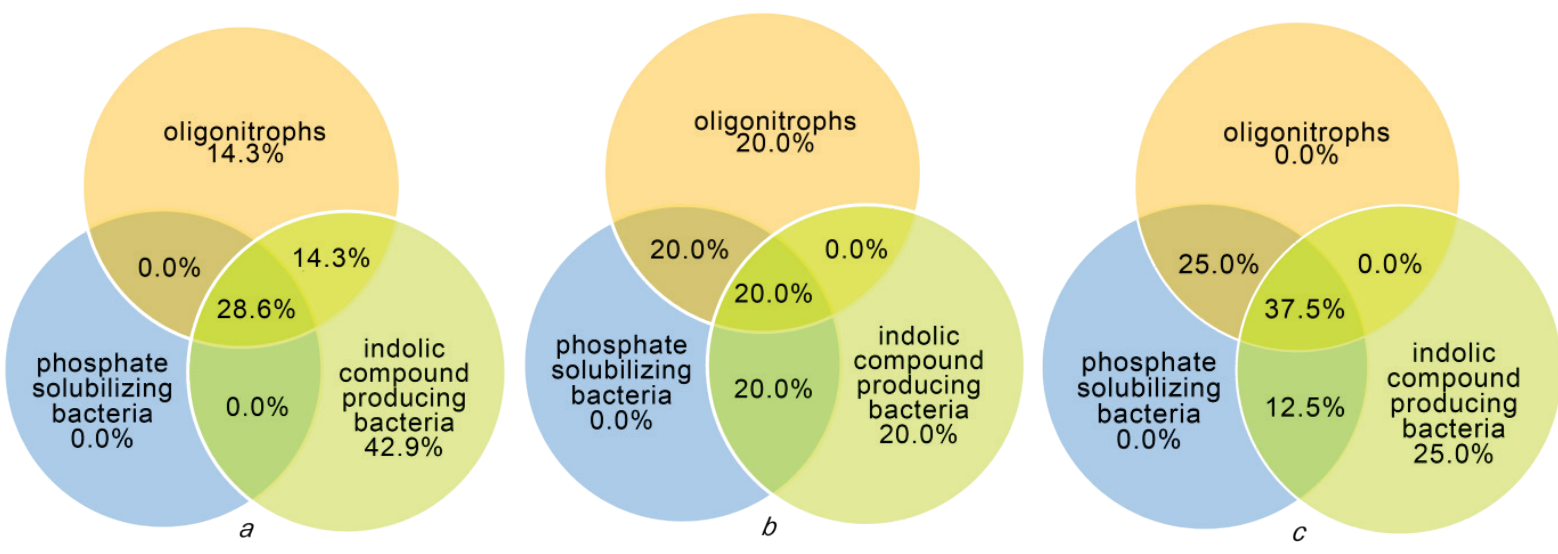

Fig. 3. Venn diagrams of grain-residing endophytic bacterial communities with single and multiple PGP activities:

numerical labels represent proportions in total count of functionally active bacteria; $a$ - grain residing endophytic community from Favorytka;

$b$ - grain -residing endophytic community from Discus; $c$ - grain -residing endophytic community from Podolianka

Identification by biochemical profiling was additionally validated by the identification by MALDI-TOF mass spectrometry. Isolate P6 was assigned to Paenibacillus peoriae with confidence value $99.9 \%$, isolate P10 - to Brevibacillus spp. with confidence value $99.9 \%$, isolate D2 - to Bacillus spp. with confidence value $99.9 \%$, isolate D5 - to Bacillus pumilus with confidence value $99.9 \%$, and isolate F1 - to Bacillus spp. with confidence value $99.9 \%$.

Differences in the composition and properties of the endophytic grain-residing community were associated with different manifestations of pathogen-induced oxidative stress and antioxidative responses in seedlings of wheat varieties with different sensitivity to $P$. syringae pv. atrofaciens. As one can see from the Figure 5a, TBARS content increment in the 7-day seedlings, which were germinated from grains treated with $P$. syringae pv. atrofaciens (as compared to their untreated counterparts), correlated with the sensitivity to the phytopathogen. Oxidative stress, as indicated by statistically significant increase of TBARS content, was registered only in seedlings of Favorytka variety, which is the least resistant to phytopatogenic bacteria according to our previous observations. It is necessary to note that TBARS content in untreated seedlings of Favorytka variety was slightly lower than that in resistant varieties Podolianka and Discus.

Antioxidative enzyme activity in seedlings germinated from grains subjected to $P$. syringae pv. atrofaciens varied markedly in wheat varieties with different sensitivity to these phytopathogenic bacteria. In treated seedlings of the wheat variety with lowest resistance to the phytopathogenic pseudomonads (Favorytka), SOD activity was 2.0 times higher than in untreated (Fig. 5b). At the same time, SOD activity in treated seedlings of wheat variety with moderate sensitivity to the phytopathogen (Discus) was 5.0 times lower than in untreated. SOD activity in treated seedlings of highly resistant variety did not differ significantly as compared to the control.

Similar to SOD activity, the fluctuation of CAT activity after the exposure to phytopathogen in studied varieties was different (Fig. 5c). CAT activity of treated seedlings of wheat varieties with low and moderate resistance to the phytopathogen was on average 2.2 times higher as compared to the corresponding controls. By contrast, CAT activity in the treated highly resistant variety was slightly lower as compared to the control. Changes in the equilibrium between the formation of hydrogen peroxide from superoxide dismutation and its decomposition by other enzymes (CAT) in wheat seedlings can be expressed by the ratio $\mathrm{R}=$
$\mathrm{SOD} / \mathrm{CAT}$. This ratio varied significantly in wheat varieties with different sensitivity to phytopathogenic pseudomonads, which were characterized by the different compositional and functional characteristics of grainresiding endophytic communities. $R$ value in untreated seedlings of Favorytka was 3.0 times higher in comparison with that in Podolyanka and did not differ from that in Discus ( 0.22 versus 0.07 and 0.21 correspondingly). After the exposure to the phytopathogen, the $\mathrm{R}$ value of Favorytka remained higher than that of resistant varieties: 3.0 times as compared to Podolyankla and 10 times as compared to Discus $(0.20$ versus 0.11 and 0.02 correspondingly).

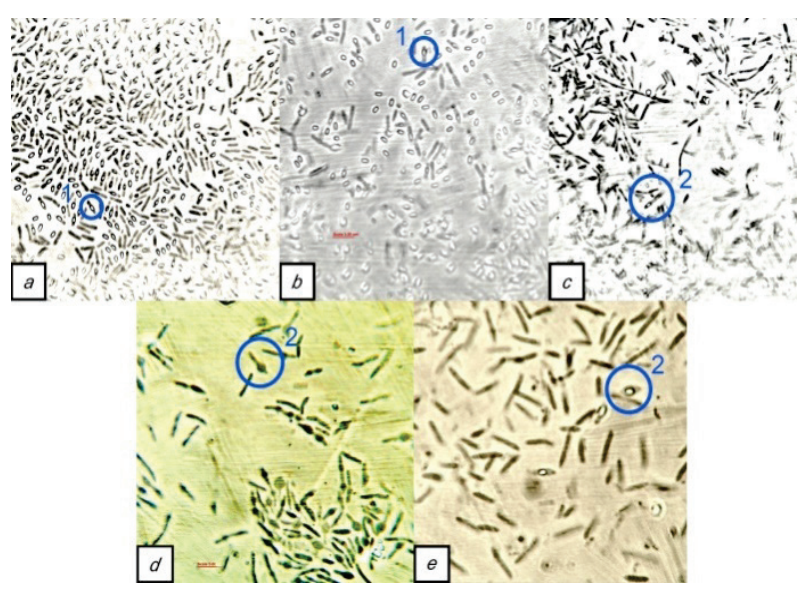

Fig. 4. Phase contrast micrographs displaying the cell morphology of wheat grain-residing bacteria with antagonistic activity against Pseudomonas syringae pv. atrofaciens (McCulloch); bar $=5 \mu \mathrm{m}$; $a-\mathrm{F} 1$ isolate from Favorytka variety, assigned to Bacillus spp; $b-\mathrm{D} 2$ isolate from Discus variety, assigned to Bacillus spp.; $c-\mathrm{D} 5$ isolate from Discus variety, assigned to Bacillus pumilus; $d-\mathrm{P} 6$ isolate from Podolianka variety, assigned to Paenibacillus peoriae; $e-\mathrm{P} 10$ isolate from Podolianka variety, assigned to Brevibacillus spp.; 1 - gram-positive rod with a sub-centrally situated ellipsoidal spore; 2 - gram-positive rod with a sub-centrally situated ellipsoidal spore that bulged the bacillary wall 
Table 2

Biochemical details of designated endophytic bacterial isolates using VITEK/BCL card

\begin{tabular}{|c|c|c|c|c|c|c|c|c|}
\hline \multirow[b]{2}{*}{ Well } & \multirow[b]{2}{*}{ Test Substrate } & \multirow[b]{2}{*}{ Mnemonic } & \multirow[b]{2}{*}{$\begin{array}{l}\text { Amount } \\
\mathrm{mg} / \text { well }\end{array}$} & \multicolumn{5}{|c|}{ Isolate } \\
\hline & & & & $\begin{array}{c}\text { F1 Bacillus } \\
\text { spp.* }\end{array}$ & $\begin{array}{l}\text { D2 Bacillus } \\
\text { spp.* }\end{array}$ & $\begin{array}{l}\text { D5 Bacillus } \\
\text { pumilus }\end{array}$ & $\begin{array}{c}\text { P6 Paenibacillus } \\
\text { peoriae }\end{array}$ & $\begin{array}{c}\text { P10 Brevibacillus brevis/ } \\
\text { Brevibacillus agri }\end{array}$ \\
\hline $1 * *$ & Beta xylosidase & BXYL & 0.0324 & + & + & + & + & - \\
\hline 3 & L-lysine arylamidase & LysA & 0.0228 & - & - & - & - & - \\
\hline 4 & L-aspartate arylamidase & AspA & 0.0240 & $(+)$ & - & - & + & $(+)$ \\
\hline 5 & Leucine-arylamidase & LeuA & 0.0234 & + & + & + & + & - \\
\hline 7 & Phenyalanine arylamidase & PheA & 0.0264 & + & + & + & + & $(-)$ \\
\hline 8 & L-proline arylamidase & ProA & 0.0234 & - & - & - & - & + \\
\hline 9 & Beta-galactosidase & BGAL & 0.0360 & + & + & + & + & - \\
\hline 10 & L-pyrrolydonyl- arylamidase & PyrA & 0.0180 & + & + & - & - & + \\
\hline 11 & alpha-galactosidase & AGAL & 0.0360 & + & + & + & + & - \\
\hline 12 & Alanine arylamidase & AlaA & 0.0222 & - & - & + & - & - \\
\hline 13 & Tyrosine arylamidase & TyrA & 0.0282 & + & + & + & $(-)$ & - \\
\hline 14 & Beta-N-acetyl-glucosaminidase & BNAG & 0.0408 & - & - & - & - & - \\
\hline 15 & Ala-Phe-Pro arylamidase & APPA & 0.0384 & - & - & - & + & + \\
\hline 18 & Cyclodextrin & CDEX & 0.3000 & - & + & - & - & - \\
\hline 19 & D-galactose & dGAL & 0.3000 & - & - & - & + & - \\
\hline 21 & Glycogen & GLYG & 0.1875 & + & $(+)$ & - & + & - \\
\hline 22 & Myo-inositol & INO & 0.3000 & + & + & $(-)$ & - & - \\
\hline 24 & Methyl-A-D-glucopyranoside acidification & MdG & 0.3000 & + & + & + & + & - \\
\hline 25 & Ellman & ELLM & 0.0300 & + & + & + & - & - \\
\hline 26 & Methyl-D-xyloside & $\mathrm{Mdx}$ & 0.300 & - & - & - & - & - \\
\hline 27 & Alpha mannosidase & AMAN & 0.0360 & - & - & + & - & - \\
\hline 29 & Maltotriose & MTE & 0.3000 & + & + & - & + & - \\
\hline 30 & Glycine arylamidase & GlyA & 0.0120 & $(-)$ & + & + & - & - \\
\hline 31 & D-mannitol & dMAN & 0.3000 & + & + & + & - & $(-)$ \\
\hline 32 & D-mannose & dMNE & 0.3000 & + & + & + & + & - \\
\hline 34 & D-melezitose & dMLZ & 0.3000 & - & - & - & - & - \\
\hline 36 & N-Acetyl-D-glucosamine & NAG & 0.3000 & - & - & - & - & - \\
\hline 37 & PAI atinose & PLE & 0.3000 & + & + & - & + & - \\
\hline 39 & L-rhamnose & IRHA & 0.3000 & - & - & - & - & - \\
\hline 41 & Beta-glucosidase & BGLU & 0.0360 & + & + & + & + & - \\
\hline 43 & Beta-mannosidase & BMAN & 0.0360 & - & $(-)$ & - & - & - \\
\hline 44 & Phosphoryl choline & PHC & 0.0366 & + & - & - & - & + \\
\hline 45 & Pyruvate & PVATE & 0.1500 & + & + & + & - & - \\
\hline 46 & Alpha-glucosidase & AGLU & 0.0360 & + & + & - & - & - \\
\hline 47 & D-tagatose & dTAG & 0.0300 & - & - & + & - & - \\
\hline 48 & D-trehalose & dTRE & 0.0300 & + & + & + & + & - \\
\hline 50 & Inulin & INU & 0.1200 & + & + & - & + & - \\
\hline 53 & D-glucose & dGLu & 0.0300 & + & + & + & + & - \\
\hline 54 & D-ribose & RIB & 0.0300 & + & + & + & + & - \\
\hline 56 & Putrescine assimilation & PSCNa & 0.2010 & - & - & - & - & - \\
\hline 58 & Growth in $6.5 \% \mathrm{NaCl}$ & $\mathrm{Nacl} 6.5 \%$ & 1.9500 & + & + & $(+)$ & - & - \\
\hline 59 & Kanamycin resistance & KAN & 0.0060 & - & - & - & + & + \\
\hline 60 & Oleandomycin resistance & OLD & 0.0030 & - & - & - & + & - \\
\hline 61 & Esculin hydrolysis & $\mathrm{ESC}$ & 0.0225 & + & + & + & + & - \\
\hline 62 & Tetrazolium red & TIZ & 0.0189 & + & + & + & $(+)$ & - \\
\hline 63 & Polymixin_B resistance & POLYB_R & 0.0009 & + & + & + & + & + \\
\hline
\end{tabular}

Note: * assigned to Bacillus subtilis / amyloliquefaciens / atrophaeus; ${ }^{* *}$ - other well numbers not designated in this table are empty; ${ }^{* * *}$ - reactions result that are shown in parentheses "(-)" or " $(+)$ " indicate weak reactions that are near to the threshold values.

Treatment of wheat grains with phytopathogenic pseudomonads affected proline content in seedling tissues (Fig. 5d). There was a significant difference between the wheat varieties in basal proline content, so that the pathogen-sensitive variety Favorytka showed significantly less basal free proline than resistant varieties Discus and Podolianka. After the exposure to the phytopathogen, proline content in Favorytka seedlings was 8.5 times higher than that in untreated. In resistant wheat varieties, we did not observe proline accumulation after the treatment with phytopathogenic bacteria.

\section{Dicussion}

Winter wheat diseases caused by $P$. syringae lead to reduction of plant growth and cereal productivity worldwide. Infected grains are one of the key sources of wheat plant colonization with this pathogen. It necessitates a better understanding of mechanisms of wheat grain resistance to phytopathogenic pseudomonads. Endophytic bacteria are considered one of the determinants of the plant resistance to phytopathogens. A major objective of this pilot study was to compare composition and biological features of grain residing endophytic bacterial communities in winter wheat varieties with different sensitivity to $P$. syringae pv. atrofaciens (McCulloch). For this purpose, we screened grain-residing endophyte collections from wheat varieties with different resistance to this phytopathogen in vitro (Pastoshchuk et al., 2018) for beneficial plant traits. Three wheat varieties were used in this study: Podolianka, Discus and Favorytka. According to the manufacturer data, Discus and Favorytka are characterized by high resistance to fungal diseases, Podolianka - by medium resistance. Our previous results indicate that resistance to fungal diseases does not correlate with the resistance to phytopathogenic pseudomonads (Pastoshchuk et al., 2018; Smirnov et al., 2020). Our current results revealed distinctions in quantitative and functional characteristics of grain-residing bacterial endophytic communities from wheat varieties with different sensitivity to phytopathogenic pseudomonads. Three bacterial morphotypes were obtained from wheat grains of all three varieties following a culturedependent protocol: gram-negative rods, endospore-forming bacilli, and gram-positive cocci. These results confirm the existence of rich microbial diversity in wheat grains, described by other scientific groups (Herrera et al., 2016; Kuźniar et al., 2020). Resistance to P. syringae pv. atrofaciens 
was associated with a high total culturable endophytic bacteria count and with the predominance of gram-negative rods or endospore-forming bacilli, but not gram-positive cocci (Fig. 6). The latter is pretty logical, since all plant beneficial traits were inherent in gram-negative rods, endospore-forming bacilli, and were absent in gram-positive cocci. High resistance to P. syringae pv. atrofaciens (McCulloch) was also associated with the highest proportion of grain-residing endophytic bacteria possessing three PGP activities simultaneously: phosphate solubilization, nitrogen fixation and production of indolic compounds. Promotion of plant growth is a multitask challenge. Therefore, endophytic bacteria possessing multiple PGP activities seem to be more powerful allies and more effective partners of the host plant as compared with their counterparts with only single PGP activity. In addition to PGP properties, culturable wheat grainresiding bacteria exerted antagonistic effect against $P$. syringae pv. atrofaciens. All endophytes with antagonistic activity belonged to endosporeforming bacilli of Bacillus, Paenibacillus and Brevibacillus genera. Resis-
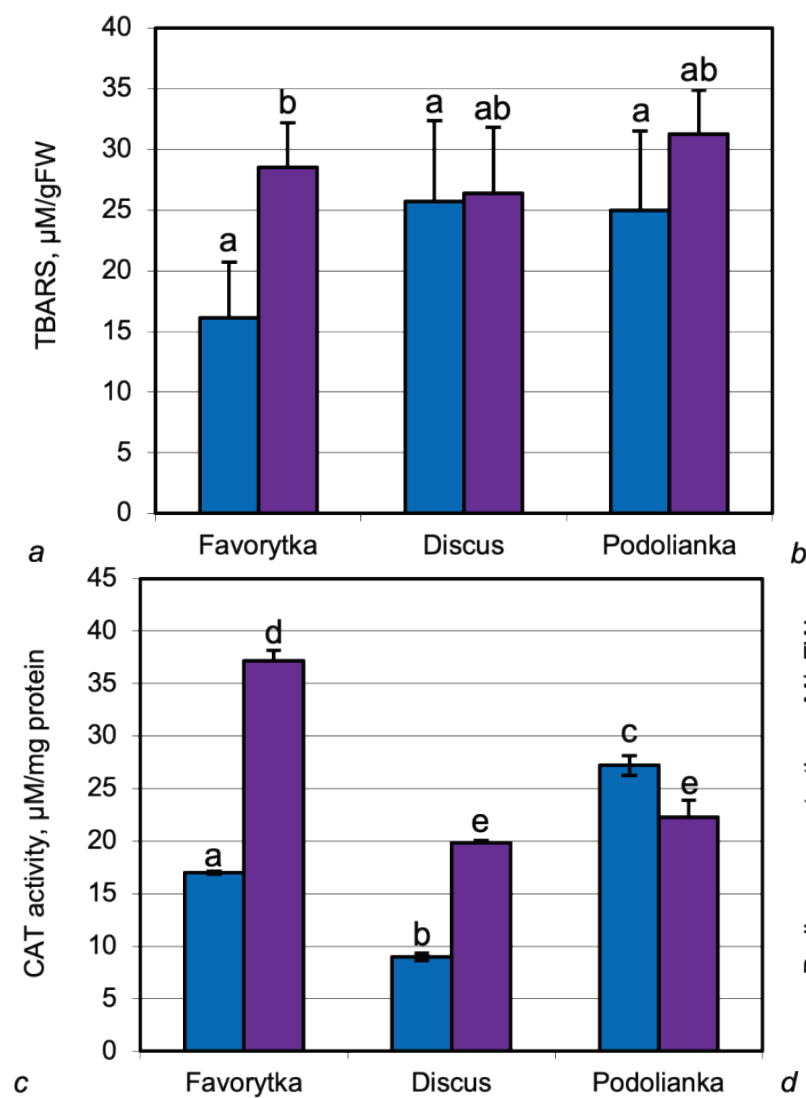

tance to $P$. syringae pv. atrofaciens was associated with a high proportion of antagonists in the total culturable endophytic bacteria count. Moreover, the grain-residing endophytic community of a highly resistant wheat variety contained Brevibacillus with most potent antagonistic activity. Our findings are consistent with literature data, according to which different Bacillus species including B. subtilis, B. amyloliquefaciens, B. pumilus etc. exert antimicrobial activity against phytopathogenic pseudomonads. Lipopeptides produced by these bacteria belong to the surfactin, iturin, and fengycin families, and are responsible for inhibition of necrotroph and hemibiotroph plant pathogens such as $P$. syringae (Nikolić et al., 2019). The efficacy of Bacillus isolates in experiments concerning P. syringae biocontrol is evidenced in several recent studies. Bacteria of Brevibacillus genus, were shown to produce non-ribosomal peptide with antimicrobial activity (marthiapeptide A), streptocidin D, and an unusual lysophospholipid, which are active against Gram-negative bacteria (Mougou et al., 2018).
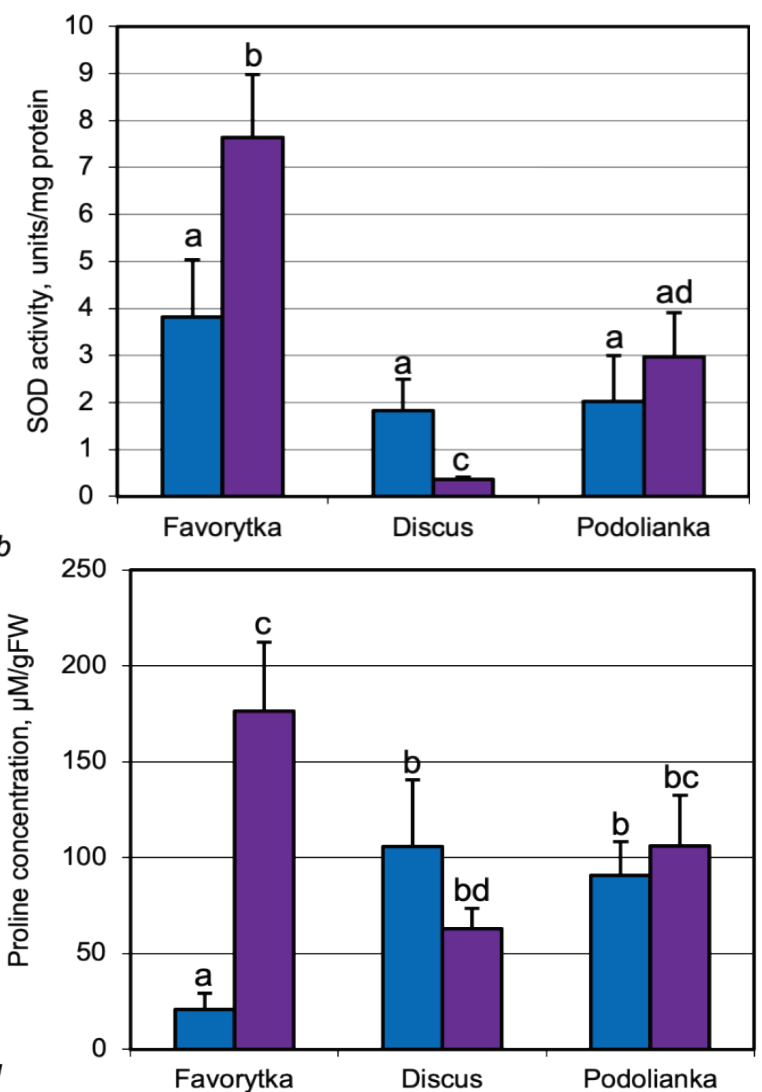

Fig. 5. Oxidative stress and antioxidative responses in wheat seedlings after grain exposure to Pseudomonas syringae pv. atrofaciens (McCulloch): $a$-thiobarbituric acid reactive substances (TBARS) content; $b$ - superoxide dismutase (SOD) activity; $c$ - catalase (CAT) activity; $d$ - proline content;

FW - fresh weight; values in bar graphs are presented as $\mathrm{x} \pm \mathrm{SD}(\mathrm{n}=5)$; different letters indicate significant differences between varieties (Tukey post-hoc test with Bonferroni correction, $\mathrm{P}<0.05$ ), except for measurements in seedlings after the exposure to phytopathogen, which were compared with their untreated counterparts individually using a two tailed T-test, $\mathrm{P}<0.05$ versus corresponding untreated control

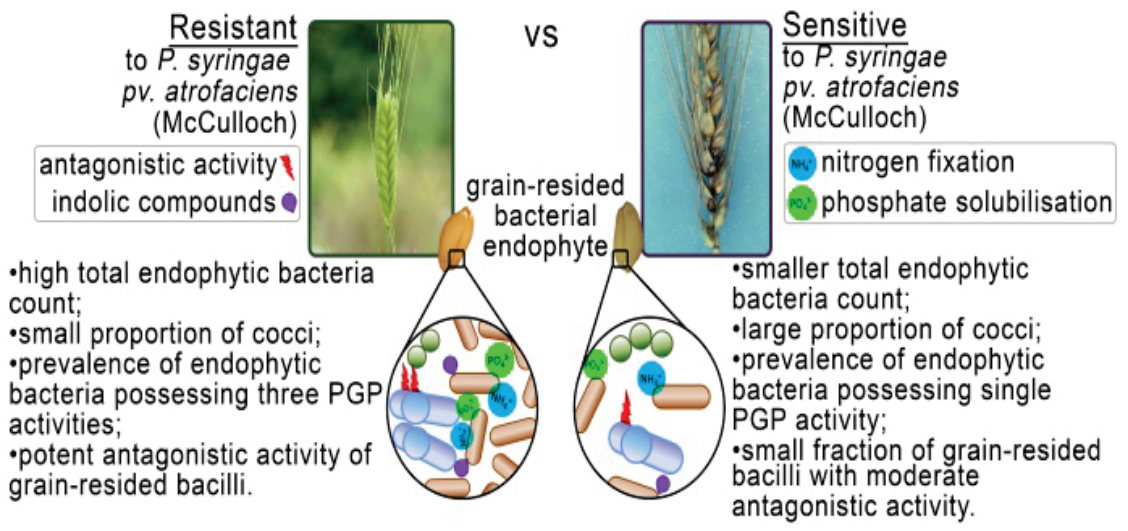

Fig. 6. Schematic representation of the features of grain-residing endophytic bacteria in winter wheat varieties with different sensitivity to Pseudomonas syringae pv. atrofaciens (McCulloch) 
Dissimilarities in grain-residing bacterial endophytic communities were also associated with different manifestation of defense reactions in response to grain exposure to phytopathogen in vitro. Resistance to $P$. syringae pv. atrofaciens was associated with the absence of oxidative stress in seedlings from grains exposed to phytopathogen. The cell susceptibility to free radicals relies on the balance between the generation of hydrogen peroxide from superoxide in the dismutation reaction catalyzed by SOD and its degradation by CAT and glutathione peroxidase, rather than on the action of separate antioxidant enzymes (Imlay, 2008). In resistant winter wheat varieties both basal and post-exposure SOD/CAT ratio values were higher than in the cells of sensitive varieties, which might result in raised hydrogen peroxide generation in response to the treatment with phytopathogen. Also, no substantial free proline accumulation was observed in resistant cultivars. Low resistance to phytopathogenic pseudomonads was associated with oxidative burst in seedling tissues along with a dramatic increase in free proline content. Wang et al. (2020) reported on the ability of endophytic bacteria to maintain oxidative-antioxidative balance in plant tissue by regulating the concentrations of $\mathrm{H}_{2} \mathrm{O}_{2}, \mathrm{MDA}$ and proline, increasing the activities of antioxidative enzymes. Mishra et al. (2018) described endophytic bacteria with the capability not only to enhance defense enzymes and antioxidant activity but also augment the expression of salicylic acid- and jasmonic acid-responsive genes in plants under pathogenic stress. We would like to pay special attention to the data on the accumulation of free proline. Recently, data on the involvement of proline in plant protection against pathogens and in the regulation of cell redox potential have appeared in the literature. Proline accumulation in plant tissue can serve to neutralize reactive oxygen species (ROS) (Meena et al., 2019). On the other hand, the accumulation of proline causes an intensification of its oxidation by proline dehydrogenase with the formation of ROS (Zeier et al., 2013). Based on the literature data (Tamosiune et al., 2017), we are inclined to assume that in this case, disproportionate free proline accumulation can contribute to ROS generation in Favorytka seedlings, whereas grain-residing endophytic plant communities of resistant cultivars can participate in the regulation of proline metabolism and therefore can prevent its inadequate accumulation. However, this assumption warrants experimental verification.

\section{Conclusion}

Our results extend current knowledge of the wheat grain-residing endophytic community and its association with the resistance to $P$. syringae pv. atrofaciens (McCulloch). To the best of our knowledge, this is the first report concerning the fluctuation of the proline content in wheat under biotic stress and its potential association with compositional and biological features of grain-residing endophytic bacteria.

Our results give reason to believe that it is necessary to search for promising strains or consortia in the endophytic community of plant varieties resistant to phytopathogens with the aim of using them in agricultural biotechnology. P6 and P10 grain-residing endophytic bacteria can be used for wheat grain dressing as PGP and biological control agents of phytopathogenic bacteria, whose contribution to wheat grain yield losses progresses at a steady pace. For this purpose, isolate identification using $16 \mathrm{~S}$ rRNA Gene Sequencing is warranted, as well as testing PGP and protective effects of isolates used alone and in composition in future in plant experiments.

The authors thank Yehor Pashkevych for his technical support in figure design.

The authors declare no conflict of interest.

\section{References}

Aebi, H. (1984). Catalase in vitro. Methods Enzymology, 105, 121-126.

Afzal, I., Shinwari, Z. K., Sikandar, S., \& Shahzad, S. (2019). Plant beneficial endophytic bacteria: Mechanisms, diversity, host range and genetic determinants. Microbiological Research, 221, 36-49.

Agarwal, H., Dowarah, B., Baruah, P. M., Bordoloi, K. S., Krishnatreya, D. B., \& Agarwala, N. (2020). Endophytes from Gnetum gnemon L. can protect seedlings against the infection of phytopathogenic bacterium Ralstonia solanacea- rum as well as promote plant growth in tomato. Microbiological Research, 238, 126503.

Alikhani, H., Saleh-Rastin, N., \& Antoun, H. (2006). Phosphate solubilization activity of rhizobia native to Iranian soils. Plant and Soil, 287, 35.

Bates, L. S., Waldren, R. P., \& Teare, I. D. (1973). Rapid determination of free proline for water-stress studies. Plant and Soil, 39, 205-207.

Beyer, W. F., \& Fridovich, I. (1987). Assaying for superoxide dismutase activity: Some large consequences of minor changes in conditions. Analytical Biochemistry, 161, 559-566.

Bezpal'ko, V. V., Stankevych, S. V., Zhukova, L. V., Zabrodina, I. V., Turenko, V.P., Horyainova, V. V., Poedinceva, A. A., Batova, O. M., Zayarna, O. Y., Bondarenko, S. V., Dolya, M. M., Mamchur, R. M., Drozd, P. Y., Sakhnenko, V. V., \& Matsyura, A. V. (2020). Pre-sowing seed treatment in winter wheat and spring barley cultivation. Ukrainian Journal of Ecology, 10(6), 255-268.

Compant, S., Cambon, M. C., Vacher, C., Mitter, B., Samad, A., \& Sessitsch, A. (2020). The plant endosphere world-bacterial life within plants. Environmental Microbiology, 23, 1812-1829.

Eevers, N., Gielen, M., Sánchez-López, A., Jaspers, S., White, J. C., Vangronsveld, J., \& Weyens, N. (2015). Optimization of isolation and cultivation of bacterial endophytes through addition of plant extract to nutrient media. Microbial Biotechnology, 8(4), 707-715.

Eid, A. M., Fouda, A., Abdel-Rahman, M. A., Salem, S. S., Elsaied, A., Oelmüller, R., Hijri, M., Bhowmik, A., Elkelish, A., \& Hassan, S. E.-D. (2021). Hamessing bacterial endophytes for promotion of plant growth and biotechnological applications: An overview. Plants, 10(5), 935.

Geisen, S., Kostenko, O., Cnossen, M. C., Ten Hooven, F. C., Vreš, B., \& van der Putten, W. H. (2017). Seed and root endophytic fungi in a range expanding and a related plant species. Frontiers in Microbiology, 8, 1645.

Herrera, D., Grossi, C., Zawoznik, M., \& Groppa, M. D. (2016). Wheat seeds harbour bacterial endophytes with potential as plant growth promoters and biocontrol agents of Fusarium graminearum. Microbiological Research, 186, 37-43.

Imlay, J. A. (2008). Cellular defenses against superoxide and hydrogen peroxide. Annual Review of Biochemistry, 77, 755-776.

Karthikeyan, G., Rajendran, L., Sendhilvel, V., Prabakar, K., \& Raguchander, T. (2021). Diversity and functions of secondary metabolites secreted by epi-endophytic microbes and their interaction with phytopathogens. In: Sudisha, J. (Ed.). Biocontrol agents and secondary metabolites: Applications and immunization for plant growth and protection. Woodhead Publishing, Cambridge. Pp. 495-517.

Kazempour, M., Kheyrgoo, M., Pedramfar, H., \& Rahimian, H. (2010). Isolation and identification of bacterial glum blotch and leaf blight on wheat (Triticum aestivum L.) in Iran. African Journal of Biotechnology, 9, 2860-2865.

Kumar, G., \& Knowles, N. R. (1993). Changes in lipid peroxidation and lipolytic and free-radical scavenging enzyme activities during aging and sprouting of potato (Solanum tuberosum) seed-tubers. Plant Physiology, 102(1), 115-124.

Kuźniar, A., Włodarczyk, K., Grządziel, J., Woźniak, M., Furtak, K., Gałązka, A., Dziadczyk, E., Skórzyńska-Polit, E., \& Wolińska, A. (2020). New insight into the composition of wheat seed microbiota. International Journal of Molecular Sciences, 21(13), 4634.

Lamichhane, J. R., Messean, A., \& Morris, C. E. (2015). Insights into epidemiology and control of diseases of annual plants caused by the Pseudomonas syringae species complex. Journal of General Plant Pathology, 81, 331-350.

Maheshwari, D. K. (2017). Endophytes: Biology and biotechnology. Springer International Publishing AG. Cambridge.

Makar, O., Kuźniar, A., Patsula, O., Kavulych, Y., Kozlovskyy, V., Wolińska, A., Skórzyńska-Polit, E., Vatamaniuk, O., Terek, O., \& Romanyuk, N. (2021). Bacterial endophytes of spring wheat grains and the potential to acquire $\mathrm{Fe}, \mathrm{Cu}$, and Zn under their low soil bioavailability. Biology, 10(5), 409.

Meena, M., Divyanshu, K., Kumar, S., Swapnil, P., Zehra, A., Shukla, V., Yadav, M., \& Upadhyay, R. S. (2019). Regulation of L-proline biosynthesis, signal transduction, transport, accumulation and its vital role in plants during variable environmental conditions. Heliyon, 5(12), e02952.

Mishra, A., Singh, S. P., Mahfooz, S., Singh, S. P., Bhattacharya, A., Mishra, N., \& Nautiyal, C. S. (2018). Endophyte-mediated modulation of defense-related genes and systemic resistance in Withania somnifera (L.) Dunal under Alternaria alternata stress. Applied and Environmental Microbiology, 84(8), e02845-17.

Morales-Cedeño, L. R., Orozco-Mosqueda, M. D. C., Loeza-Lara, P. D., Parra-Cota, F. I., de Los Santos-Villalobos, S., \& Santoyo, G. (2020). Plant growth-promoting bacterial endophytes as biocontrol agents of pre- and post-harvest diseases: Fundamentals, methods of application and future perspectives. Microbiological Research, 242, 126612.

Mougou, I., \& Boughalleb-M'hamdi, N. (2018). Biocontrol of Pseudomonas syringae pv. syringae affecting citrus orchards in Tunisia by using indigenous Bacillus spp. and garlic extract. Egyptian Journal of Biological Pest Control, 28, 60.

Muthukumar, A., Regunathan, U., \& Ramasamy, N. (2017). Role of bacterial endophytes in plant disease control. In: Maheshwari, D. K., \& Annapurna, K. (Eds.). Endophytes: Crop productivity and protection. Vol. 2. Springer International Publishing AG. Cham. Pp. 131-161. 
Nikolić, I., Berić, T., Dimkić, I., Popović, T., Lozo, J., Fira, D., \& Stanković, S. (2019). Biological control of Pseudomonas syringae pv. aptata on sugar beet with Bacillus pumilus SS-10.7 and Bacillus amyloliquefaciens (SS-12.6 and SS38.4) strains. Journal of Applied Microbiology, 126(1), 165-176.

Papik, J., Folkmanova, M., Polivkova-Majorova, M., Suman, J., \& Uhlik, O. (2020). The invisible life inside plants: Deciphering the riddles of endophytic bacterial diversity. Biotechnology Advances, 44, 107614.

Pasichnyk, L. A. (2016). The spectrum of weed phytopathogens in wheat agrophytocenosis. Mikrobiolohichnyi Zhurnal, 78(6), 19-28.

Pastoshchuk, A. Y., Skivka, L. M., Butsenko, L. M., \& Patyka, V. P. (2018). Vplyv zbudnyka bazalnoho bakteriozu na prorostannia zeren ta rist parostkiv pshenytsi riznykh sortiv [Effect of causal agent of basal bacteriosis on seed germination and root growth of different wheat varieties]. Mikrobiolohiia i Biotekhnolohiia, 42, 39-48 (in Ukrainian)

Rana, A., Kabi, S. R., Verma, S., Adak, A., Pal, M., Shivay, Y. S., Prasanna, R., \& Nain, L. (2015). Prospecting plant growth promoting bacteria and cyanobacteria as options for enrichment of macro- and micronutrients in grains in rice-wheat cropping sequence. Cogent Food and Agriculture, 1, 1037379.

Ridout, M. E., Schroeder, K. L., Hunter, S. S., Styer, J., \& Newcombe, G. (2019). Priority effects of wheat seed endophytes on a rhizosphere symbiosis. Symbiosis, 78, 19-31.

Rychert, J., Burnham, C. A., Bythrow, M., Garner, O. B., Ginocchio, C. C., Jennemann, R., Lewinski, M. A., Manji, R., Mochon, A. B., Procop, G. W., Richter, S. S., Sercia, L., Westblade, L. F., Ferraro, M. J., \& Branda, J. A. (2013). Multicenter evaluation of the Vitek MS matrix-assisted laser desorption ionizationtime of flight mass spectrometry system for identification of gram-positive aerobic bacteria. Journal of Clininical Microbiology, 51(7), 2225-2231.
Sadaf, S., Nuzhat, A., \& Khan, N. S. (2009). Indole acetic acid production and enhanced plant growth promotion by indigenous PSBs. African Journal of Agricultural Research, 4(11), 1312-1316.

Smirnov, O., Karpets, L. A., Zinchenko, A., Kovalenko, M., Belava, V., \& Taran, N. (2020). Changes of morphofunctional traits of Triticum aestivum and Triticum dicoccum seedlings caused by polyethylene glycol-modeling drought. Journal of Central European Agriculture, 21(2), 268-274.

Tamosiune, I., Baniulis, D., \& Stanys, V. (2017). Role of endophytic bacteria in stress tolerance of agricultural plants: Diversity of microorganisms and molecular mechanisms. In: Kumar, V., Kumar, M., Sharma, S., \& Prasad, R. (Eds.). Probiotics in agroecosystem. Springer, Singapore. Pp. 1-29.

Umesha, S. (2020). Diversity of seed-borne bacterial phytopathogens. In: Kumar, R., \& Gupta, A. (Eds.). Seed-borne diseases of agricultural crops: Detection, diagnosis and management. Springer, Singapore. Pp. 307-328.

Valencia-Botín, A. J., \& Cisneros-López, M. E. (2012). A review of the studies and interactions of Pseudomonas syringae pathovars on wheat. International Journal of Agronomy, 2012, 692350.

Wang, Q., Ge, C., Xu, S. Wu, Y., Sahito, Z. A., Ma, L., Pan, F., Zhou, Q., Huang, L., Feng, Y., \& Yang, X. (2020). The endophytic bacterium Sphingomonas SaMR12 alleviates Cd stress in oilseed rape through regulation of the GSHAsA cycle and antioxidative enzymes. BMC Plant Biology, 20(1), 63.

Woźniak, M., Gałązka, A., Tyśkiewicz, R., \& Jaroszuk-Ścisel, J. (2019). Endophytic bacteria potentially promote plant growth by synthesizing different metabolites and their phenotypic/physiological profiles in the Biolog GEN III MicroPlateTM test. International Journal of Molecular Sciences, 20(21), 5283.

Zeier, J. (2013). New insights into the regulation of plant immunity by amino acid metabolic pathways. Plant Cell and Environment, 36(12), 2085-103. 